\title{
PROCALCITONIN IN EARLY PREDICTION OF ACUTE SEVERE PANCREATITIS
}

D0I: 10.36740/WLek202007112

\author{
Volodymyr V. Kasian, Volodymyr D. Sheiko, Tetiana V. Mamontova, Liudmyla E. Vesnina, Oksana A. Shlykova \\ UKRAINIAN MEDICAL STOMATOLOGICAL ACADEMY, POLTAVA, UKRAINE
}

\begin{abstract}
The aim of the study was to analyze the prognostic potential of procalcitonin in acute pancreatitis complicated by ascites-peritonitis.

Materials and methods: The study analyzed the results of a comprehensive examination and treatment of 18 patients with acute pancreatitis complicated by enzymatic ascites-peritonitis, including 13 patients who were treated in the surgical department of KP "Poltava Regional Clinical Hospital. MV Sklifosovsky POR", and 5 patients of other emergency hospitals in Poltava, in the period from 2017 to 2019. In addition to standard screening methods, these patients were additionally tested for procalcitonin to predict an adverse course in the early period.

Results: To assess the relationship between the presence of elevated procalcitonin levels at the time of hospitalization of $0.5 \mathrm{ng} / \mathrm{ml}$ and above and unsatisfactory treatment results, differences were assessed using an accurate Fisher test. When comparing differences in the development of infectious complications in the dynamics of the disease in patients of the study group depending on the presence of elevated concentrations of procalcitonin or its absence at the time of hospitalization, a significant difference was found ( $p<0.05$ ). Conclusions: In our opinion, the use of procalcitonin as a predictor of infectious complications in the dynamics of the disease will determine the category of patients in whom reducing the risk of flora translocation through the use of early oral antibiotic prophylaxis and parenteral drugs tropic to pancreatic tissue may reduce the incidence of purulent complications. In another category of patients, antibacterial therapy is not advisable due to the low risk of purulent-septic complications.
\end{abstract}

KEY WORDS: acute pancreatitis, procalcitonin, ascites-peritonitis, severity of the condition

Wiad Lek. 2020;73(7):1370-1372

\section{INTRODUCTION}

Acute severe pancreatitis manifests itself as a sudden and important occurrence with a rapid deterioration of hopes [1]. Ascites-peritonitis in acute pancreatitis are quite common results of the early period of action[2]. During the first week of acute severe pancreatitis, in most cases death occurs as a result of multiple organ failure, in the following weeks, the infection plays a more important role [3]. Tang J.C.F. [3] recommends identifying patients with acute pancreatitis who are most in need of aggressive medical care, differentiating the severity of their disease.

Severity prediction is a valuable tool in the clinic, but in order to increase clinical benefit, it must anticipate real severity factors - (peri) pancreatic necrosis and / or organ failure [4]. Identification of early markers is important because there is a concern, especially among resuscitators, that patients are often hospitalized in the intensive care unit too late [5].

In the article "Predicting the prognosis of acute pancreatitis" C. Forsmark, D. Yadav [6] point to the need to identify the best biological markers of the main factors that determine the outcome - organ failure and pancreatic necrosis, as well as factors related to with the development of severe systemic inflammatory response to pancreatic necrosis as well as factors of the patient's body associated with development severe systemic inflammatory response to pancreatic necrosis. This approach can help in understanding the mechanisms of severe disease, identifying patients at risk shortly after or before damage to pancreatic tissue, and developing treatments to reduce the severity of the disease [6].
Procalcitonin is an inactive 116-amino acid propeptide of the biologically active hormone calcitonin, which, as first described, is characterized by significant concentrations in patients with bacterial and fungal infections [7].

According to the recommendations of WSES 2019, the level of procalcitonin $3.8 \mathrm{ng} / \mathrm{ml}$ and above 96 hours after the onset of the disease indicates pancreatic necrosis with a sensitivity of $93 \%$ and a specificity of $79 \%[8,9]$.

Antibiotics are always recommended for the treatment of infected severe acute pancreatitis. However, the diagnosis of infected pancreatitis is difficult because the clinical picture is no different from the inflammatory reaction caused by pancreatitis itself. The timing of infection in pancreatic necrosis is variable and unpredictable, although their peak is observed mainly from the second to the fourth week from the onset of the disease. Clinical signs are characterized by high sensitivity, but insufficient specificity $[10,11]$.

Procalcitonin is a promising serological marker of pancreatic infection, especially pancreatic infection in combination with organ failure [12]. Specificity for procalcitonin in the meta-analysis ranging from 83 to $91 \%[13,14]$.

\section{THE AIM}

The aim of the study was to analyze the prognostic potential of procalcitonin in acute pancreatitis complicated by ascites-peritonitis. 
Table I. Procalcitonin level at the time of hospitalization and after 72 hours.

\begin{tabular}{ccccc}
\hline $\begin{array}{c}\text { Procalcitonin level } \\
\text { (ng / ml) }\end{array}$ & \multicolumn{2}{c}{$\begin{array}{c}\text { at the time of } \\
\text { hospitalization }\end{array}$} & after $\mathbf{7 2}$ hours \\
\cline { 2 - 5 } & Abs. & $\%$ & Abs. & $\%$ \\
\hline$<0,1$ & 2 & 11 & 1 & 6 \\
\hline $0,1-0,4$ & 9 & 50 & 11 & 61 \\
\hline $0,5-2$ & 4 & 22 & 4 & 22 \\
\hline $2,1-10$ & 3 & 17 & 2 & 11 \\
\hline$>10$ & 0 & 0 & 0 & 0 \\
\hline
\end{tabular}

Table II. Differences in the presence of unsatisfactory treatment results depending on the presence or absence of elevated concentrations of procalcitonin at the time of hospitalization were determined by Fisher's exact test

\begin{tabular}{ccccccc}
\hline & \multicolumn{3}{c}{$\begin{array}{c}\text { Elevated procalcitonin } \\
\text { concentration }\end{array}$} & \\
& \multicolumn{2}{c}{ of $\mathbf{0 . 5} \mathbf{~ n g ~ / ~ m l ~ a n d ~ a b o v e ~}$} & p \\
\cline { 2 - 5 } & \multicolumn{2}{c}{ Missing } & \multicolumn{3}{c}{ Available } & \\
\cline { 2 - 5 } & Abs. & $\%$ & Abs. & $\%$ & \\
\hline Death & 1 & 6 & 3 & 17 & 0,093 \\
\hline $\begin{array}{c}\text { Organ dysfunction } \\
\text { after 72 hours }\end{array}$ & 3 & 17 & 5 & 28 & 0,066 \\
\hline $\begin{array}{c}\text { Development of } \\
\text { infectious complications }\end{array}$ & 1 & 6 & 6 & 33 & 0,005 \\
\hline
\end{tabular}

\section{MATERIALS AND METHODS}

The study analyzed the results of a comprehensive examination and treatment of 18 patients with acute pancreatitis complicated by enzymatic ascites-peritonitis, including 13 patients who were treated in the surgical department of KP "Poltava Regional Clinical Hospital. MV Sklifosovsky POR ", and 5 patients of other emergency hospitals in Poltava, in the period from 2017 to 2019.

In addition to standard screening methods, these patients were additionally tested for procalcitonin to predict an adverse course in the early period.

Statistical analysis of the study materials was performed using the program "STATISTICA 10.0" (StatSoft, Inc., USA) by methods of descriptive statistics with the calculation in the studied groups of quality indicators in the form of frequencies and their percentages.

The statistical significance of differences was determined by a nonparametric method between the indicators of independent groups using Fisher's exact criterion. Differences at $\mathrm{p}<0.05$ were considered statistically significant for all types of analysis.

This set of statistical methods for evaluating the results of treatment allowed to obtain evidence-based results.

\section{RESULTS AND DISCUSSION}

We studied the level of procalcitonin during hospitalization and after 72 hours in patients with acute pancreatitis complicated by ascites-peritonitis. Enzyme-linked immunosorbent assays were performed on the basis of the Research
Institute of Genetic and Immunological Foundations of Pathology and Pharmacogenetics "UMSA", Poltava. The level of procalcitonin was determined using a test system: "A set of reagents for enzyme-linked immunosorbent assay of procalcitonin concentration in human serum (plasma)" Procalcitonin-IFA-BEST “, VECTOR-BEST, Russia”.

In patients of the study group, the values of procalcitonin at the time of hospitalization and after $72 \mathrm{~h}$ were distributed as follows (Table I).

To assess the relationship between the presence of elevated procalcitonin levels at the time of hospitalization of $0.5 \mathrm{ng} / \mathrm{ml}$ and above and unsatisfactory treatment results, differences were assessed using an accurate Fisher test.

The following indicators were selected as criteria and target points for the analysis of disease dynamics:

1. Organ dysfunction after 72 hours

2. Development of infectious complications in the dynamics of the disease.

3. Mortality (Table II).

When comparing differences in the development of longterm organ dysfunction and mortality in patients of the study group depending on the presence of elevated concentrations of procalcitonin or its absence at the time of hospitalization, no significant difference was found ( $p>0.05)$.

When comparing differences in the development of infectious complications in the dynamics of the disease in patients of the study group depending on the presence of elevated concentrations of procalcitonin or its absence at the time of hospitalization, a significant difference was found $(\mathrm{p}<0.05)$

According to the recommendations of WSES 2019, the level of procalcitonin $3.8 \mathrm{ng} / \mathrm{ml}$ and above 96 hours after the onset of the disease indicates pancreatic necrosis with a sensitivity of $93 \%$ and a specificity of $79 \%[8,9]$. At the time of hospitalization, at the time of hospitalization and after 72 hours in patients of the study group, the concentration of procalcitonin did not exceed $3.8 \mathrm{ng} / \mathrm{ml}$. However, procalcitonin is recognized as an effective predictor of the severity of acute pancreatitis and the risk of developing infected pancreatitis [7]. A number of studies demonstrate the effectiveness of determining the serum concentration of procalcitonin in predicting the risk of infected pancreatic necrosis [13,15-17]. Therefore, in predicting the course of pancreatitis, the following indicators are important:

- $0.5 \mathrm{ng} / \mathrm{ml}$ during hospitalization and maintaining the level of increase in the dynamics;

- above $2.0 \mathrm{ng} / \mathrm{ml}$ is traditionally interpreted as a high risk of need for surgery for infectious complications;

- ng / ml 96 hours after the onset of the disease indicates infected pancreatic necrosis.

Values of procalcitonin concentration of $0.5 \mathrm{ng} / \mathrm{ml}$ and more are interpreted as pathological and can be used to predict the severity of acute pancreatitis and the development of infected pancreatic necrosis in the dynamics of the disease [13].

The obtained results suggest that the change in treatment tactics in patients with acute severe pancreatitis complicated by ascites-peritonitis who have elevated procalci- 
tonin levels (>0.5 $\mathrm{ng} / \mathrm{ml})$ at the time of hospitalization and maintenance / increase of its level in the dynamics at re-examination after $72 \mathrm{~h}$ may help reduce the risk of purulent-septic complications.

\section{CONCLUSIONS}

In our opinion, the use of procalcitonin as a predictor of infectious complications in the dynamics of the disease will determine the category of patients whose risk of translocation of flora is reduced by the use of early oral antibiotic prophylaxis and parenteral drugs tropic to pancreatic tissues may reduce the incidence of purulent complications. In another category of patients, antibacterial therapy is not advisable due to the low risk of purulent-septic complications.

\section{REFERENCES}

1. Sheiko V.D., Ohanezian A.H. Vplyv zrilosti pankreatohennykh obmezhenykh skupchen ridyny na efektyvnist punktsiino-drenuvalnykh vtruchan pid kontrolem UZD [Influence of maturity of pancreatogenic limited clusters on the effectiveness of puncture and drainage interventions under ultrasound control]. Aktualni pytannia suchasnoi medytsyny: Visn. Ukr. med. stomat. Akademii. 2015;15:145-54. (in Ukrainian)

2. Kasian V.V., Cherkun 0.Y., Sytnik D.A., Sheiko V.D. Surgical tactics with acute pancreatitis complicated ascites-peritonitis [Khirurhichna taktyka pry hostromu pankreatyti, shcho uskladnenyi astsyt- perytonitom]. Zaporozhye Med J. 2019;21(4):522-7. (in Ukrainian)

3. Tang J.C.F. Acute Pancreatitis. Nejm. 2017. p. 1-13.

4. Petrov M.S. Predicting the severity of acute pancreatitis: Choose the right horse before hitching the cart. Dig Dis Sci. 2011;56(12):3402-4.

5. Dellinger E.P., Forsmark C.E., Layer P., et al. Determinant-Based Classification of Acute Pancreatitis Severity. Ann Surg [Internet]. 2012;256(6):875-80.

6. Forsmark C.E., Yadav D. Predicting the Prognosis of Acute Pancreatitis. Ann Intern Med. 2016;165(7):523-5.

7. Assicot M., Gendrel D., Carsin H. High serum procalcitonin concentrations in patients with sepsis and infection. Lancet. 1993;(341):515-8.

8. Staubli S.M., Oertli D., Nebiker C.A. Laboratory markers predicting severity of acute pancreatitis. Crit Rev Clin Lab Sci. 2015;52(6):273-83.

9. Yang C.J., Chen J., Phillips A.R.J., et al. Predictors of severe and critical acute pancreatitis: A systematic review. Dig Liver Dis. 2014;46(5):44651. D0l: $10.1016 /$ j.dld.2014.01.158

10. DeWaele J.J. Rational use of antimicrobials in patients with severe acute pancreatitis. Semin Respir Crit Care Med. 2011;32(2):174-80.

11. Stigliano S., Sternby H., de Madaria E., et al. Early management of acute pancreatitis: A review of the best evidence. Dig Liver Dis. 2017;49(6):585-94.
12. Rau B.M., Kemppainen E.A., Gumbs A.A., et al. Early Assessment of Pancreatic Infections and Overall Prognosis in Severe Acute Pancreatitis by Procalcitonin (PCT). Ann Surg. 2007;245(5):745-54.

13. Mofidi R., Suttie S.A., Patil P.V., et al. The value of procalcitonin at predicting the severity of acute pancreatitis and development of infected pancreatic necrosis: Systematic review. Surgery. 2009;146(1):72-81.

14. Purkayastha S., Chow A., Athanasiou T., et al. Does serum procalcitonin have a role in evaluating the severity of acute pancreatitis? A question revisited. World J Surg. 2006;30(9):1713-21.

15. Chen H.Z., Ji L., Li L., Wang G., et al. Early prediction of infected pancreatic necrosis secondary to necrotizing pancreatitis. Med (United States). 2017;96(30).

16. Rau B., Steinbach G., Baumgart K., et al. The clinical value of procalcitonin in the prediction of infected necrosis in acute pancreatitis. Intensive Care Med Suppl. 2000;26(2):159-64.

17. Adachi T., Kishihara Y., Okano H., et al. The utility of procalcitonin for the patients with infected pancreatic necrotic and pancreatic abscess. Intensive Care Med Exp. 2015;3(S1):1-2.

The work is a fragment of the GDR "Differentiated surgical tactics for parapancreatic infectious-septic complications of destructive pancreatitis" (№ state registration 0116U005439).

\section{ORCID and contributionship:}

Volodymyr V. Kasian: 0000-0003-2933-041X ${ }^{A, B, C, D, E, F}$

Volodymyr D. Sheiko: 0000-0001-9862-6543 A,E,F

Tetiana V. Mamontova: 0000-0003-4967-9379 B,C,F

Liudmyla E. Vesnina: 0000-0003-3068-6237 ${ }^{E, F}$

Oksana A. Shlykova: 0000-0002-6764-2767 E,F

\section{CORRESPONDING AUTHOR Volodymyr V. Kasian \\ Department of surgery № 2 , \\ Ukrainian Medical Stomatological Academy, \\ 23 Shevchenko Str., 36011, Poltava, Ukraine \\ tel: +380 999656150 \\ e-mail: kasianv88@gmail.com}

Received: 01.03 .2020

Accepted: 19.06 .2020

A - Work concept and design, B - Data collection and analysis, C - Responsibility for statistical analysis,

D-Writing the article, $\mathbf{E}$-Critical review, $\mathbf{F}$ - Final approval of the article 